\title{
К ВОПРОСУ ОПРЕДЕЛЕНИЯ ПОНЯТИЯ «ПРАВОВОЙ РЕЖИМ»
}

\section{ABOUT THE QUESTION OF THE DEFINITION OF THE CONCERT « LEGAL REGIME»}

I. Zueva

Summary. In modern realities, when political and socio-economic transformations take place, the development of the legal system in the state also undergoes changes, of course this could not, but would not affect such a category of legal management as the legal regime. After all, the establishment of a legal regime in a particular industry is to ensure the national security of the state, and guaranteed observance of the constitutional rights and freedoms of citizens. In the article, the author will consider the scientific, different points of view of legal scholars, to the question of the emergence and development of the legal nature of the concept of "legal regime" and its structure. Both the general theoretical nature and the critical opinion of the formed approaches will be noted, the author will consider the characteristics of the concept itself, the content and structure, the regulation procedure, a new approach to the author's definition of the legal regime will be proposed.

Keywords: legal regime, legal order, mandatory requirements, legal regulation, management.

\author{
Зуева Ирина Борисовна \\ Аспирант, Институт государства и права \\ Российской академии наук \\ zueva_irina44@mail.ru
}

Аннотация. В современных реалиях, когда происходят политические и социально - экономические преобразования, развитие правовой системы в государстве также, претерпевает изменения, конечно это не могло, не отразится на такой категории юридического управления как правовой режим. Ведь установление правового режима в той или иной отрасли, это обеспечение национальной безопасности государства, и гарантированное соблюдение конституционных прав и свобод граждан. В статье, автором, будут рассмотрены научные, различные точки зрения ученых правоведов, к вопросу о возникновении и развитии юридической природы понятия «правовой режим» и его структура. Отмечен будет и общетеоретический характер, и критическое мнение сформировавшихся подходов, автором будет рассмотрена характеристика самого понятия, содержание и структура, порядок регулирования, будет предложен новый подход авторского определения правового режима.

Ключевые слова: правой режим, правой порядок, обязательные требования, правовое регулирование, управление.
$\mathbf{K}$ онституция Российской Федерации провозглашает права и свободы человека и гражданина высшей ценностью. Их признание, соблюдение и защита - обязанность государства. Обеспечение прав и свобод человека и гражданина осуществляется различными правовыми средствами. Одним из них является правовой режим. Не случайно, потому что, определение сущности правового режима, его значения для общества и государства, не осталось без внимания ученых-юристов, прежде всего, административистов и теоретиков государства и права. Достаточно назвать труды таких авторов, как С.С. Алексеев, Д.Н. Бахрах, А.В. Малько, Н.И. Матузов, А.Ф. Ноздрачев, С.М. Петров, Б.В. Россинский, В.Б. Рушайло, Ю.Н. Старилов, посвященные рассмотрению различных аспектов правового режима.

Анализируя ранее изданные труды ученых-юристов, можно уверенно констатировать то, что сформированные ими подходы к определению сущности правового режима сохраняют актуальность в условиях современных конституционных реалий. Вместе с тем сохраняется ряд дискуссионных моментов, которые так и не получили однозначного понимания в юридической науке.

Поэтому представляется важным проанализировать научные взгляды, на правовой режим, сформировавшиеся к настоящему времени в отечественной юридической науке. Без такого анализа вряд ли возможно дальнейшее развитие научных представлений о правовом режиме в современном этапе общественного развития и государственного строительства.

В специальной литературе отмечалось, что термин «правой режим» был впервые введен в научный оборот В нашей стране академиком А.В. Венедиктовым, который писал о правовом режиме государственной собственности [17, с. 139]. Известны и более ранние исследования правового режима. Так, видный французский правовед Леон Дюги (1859-1928) полагал, что правовой режим - это тот режим, при котором индивидуальная физическая, умственная моральная и религиозная деятельность может, в принципе, свободно проявляться без какого-нибудь предварительного ограничения, без какой-нибудь предварительной авторизации, и тогда, 
когда индивидуальная деятельность проявляется противно праву законодатель уполномочивает публичную власть выступить, чтобы наказать, принудить к возмещению или отменить [5, с. 706].

«Правой режим» в его понимании Леоном Дюги указывало на возникновение публично-правовых отношений между властью и народом, где именно власть в лице государственных органов, применяет на основе закона юридически значимые средства такие как дозволения, запреты и поощрения. Именно в этом и есть, как представляется, суть правового государства. И здесь уместно вспомнить известного русского дореволюционного правоведа В.М. Гессена, который глубоко верно писал: «правовое государство характеризуется отношением власти к закону» [3, с. 2016].

Смена общественного строя неизбежно приводит к формированию устоев новой власти, изменениям правового регулирования, которые оказывают влияние на общество и само государство. После Октябрьской революции 1917 года характер научных трудов об управлении и государстве, административном праве кардинально изменился. Произошло переосмысление отношений между государством и гражданином. Отвергались ранее сформированные взгляды, так называемой «буржуазной науки», чуждой социалистическому государству, основанному на марксистско-ленинской идеологии.

В качестве примера можно привести критическую статью, в которой освещалось обсуждение учеными-юристами учебника «Советское административное право» [6, с. 431], вышедшего в 1946 году под редакцией известных советских административистов И.И. Евтихеева и В.А Власова. Так, в указанной статье А.С. Спекторов писал: «обсуждаемой книге чужд боевой, наступательный характер, какого вправе мы требовать от советской книги по административному праву. Книга не связана с действительностью, с современной исторической обстановкой, а необходимость этой связи в учебнике является элементарным требованием [13, с. 63]. Критически выступил в отношении учебника также и С.С. Студеникин. Он, в частности, отметил: «учебник не воспитывает читателей в духе социалистического патриотизма, понимания превосходства советской системы государственного управления, он не прививает чувства уважения к социалистической государственности, правопорядку и законности» [13, с. 65].

Поэтому, есть основания полагать, что в послереволюционный период, понятие правой режим не освещалось. Научные труды той эпохи, в основном делали акцент на новый общественный строй, которому было присуща исполнительно-распорядительная деятельность, на основе которой осуществлялось государственное управление, формировалась новая государственная служба. При таком положении термин «режим» в основном использовался не иначе как как вид управления-действия, к примеру: режим экономии, режим труда, санитарный режим и т.д. [6, с. 280].

Видный теоретик С.С. Алексеев, выделил разрешительный тип правового регулирования - РР-порядок. Ученый писал: «РР — порядок, заключается в том, что он является оптимальным способом упорядочения деятельности государственных органов, должностных лиц, обеспечивающих введение властных функций в строгие рамки и существенного ограничивая возможности произвольных действий» [1, с. 165]. В интерпретации С.С. Алексеева «правой режим» представляет собой порядок регулирования с набором комплекса правовых средств через сочетание дозволений, запретов, обязываний и т.д. [1, с. 185].

Автор настоящей статьи не преследует цель рассмотреть все научные взгляды на понятие «правовой режим». Цель видится в другом, а именно в том, чтобы определить, как во времени эволюционировало это понятие, как следует его понимать ныне, а также показать направления его дальнейшего развития.

В свое время С.С. Алексеев верно заметил, что «право потому и «право», что оно «говорит о правах», является устойчивым государственно-властным критерием юридически дозволенного и недозволенного в области поведения людей со всеми вытекающими отсюда правовыми институтами, правовыми средствами и механизмами [1, с. 136]. В полной мере понимание права, предложенное С.С. Алексеевым, относится и к такому явлению, как «правовой режим».

Положения теории преломляются в отраслевых юридических науках и, в частности, в науке административного права. Так, развернутое определение понятия «правовой режим» дает Д.Н. Бахрах. В его интерпретации это «официально установленный особый порядок правового регулирования, отражающий совокупность юридических и организационных средств, используемых для закрепления социально-правового состояния объектов воздействия и направленный на обеспечение их устойчивого функционирования» [2, с. 478]. По мнению Ю.М. Козлова и Л.Л. Попова, административный режим есть, цитируем, «основанный на нормах административного права особый порядок функционирования его субъектов, направленный на преодоление негативных явлений соответствующей сфере государственного управления» [7, с. 468]. В свою очередь Б.В. Россинский полагает, что правовой режим - это «установленный особый порядок правового регулирования, отражаю- 
щий совокупность юридических и организационных средств, используемых для закрепления социальноправового состояния объектов воздействия, направленный на обеспечение их устойчивого развития» [11, c. 386].

Анализ юридической литературы позволяет говорить, что многие авторы используют весьма широкое понятие «правовой» режим, данное в свое время Н.И. Матузовым и А.В. Малько [9, с. 17-18]. Вместе с тем, Ю.А. Тихомиров отмечает, «такая чрезмерно широкая характеристика как бы стирает грань между известными категориями права и затрудняет выделение специфических признаков правового режима» [15, с. 400].

По мнению автора настоящей статьи, определяя подход к понятию «правовой режим», следует выделять его как особый действующий или временный порядок с закрепленными юридическими средствами и методами правового регулирования, в современном подходе либо дополняют его или видоизменяют перефразированием в иной интерпретации, но само понятие все же неизменно.

Нельзя не признать, что в отечественной юридической науке пока нет единообразного подхода к определению понятия «правой режим». Доминирует точка зрения тех авторов, которые считают, что правой режим это установленный порядок регулирования публично-правовых отношений, сложившихся между органами государственной власти и гражданами. В частности, это отмечает Г.С. Беляева. Она указывает на то, что обозначенная проблема усугубляется еще и тем, что даже в рамках узкоотраслевых исследований понятие правового режима часто и используется как «обиходное», уже известное и не нуждающееся в уточнении, а правовой режим нередко упоминается только в названии работы [10]. Иную точку зрения имеет А.П. Ситников, который предлагает «ограничить правовой режим от таких категорий, как правовой порядок, правовое состояние, и тем самым определить место специальных правовых режимов в системе правовых средств, используемых государством в целях обеспечения безопасности граждан и защиты конституционного строя» $[14$, с. 11]. Другой автор, И.И. Лясковский, отошёл от определения понятия «правовой режим» не иначе, как порядок. Он сформулировал достаточно сложную для восприятия структуру определения понятия «правовой режим» и определил его как «систему регулирования, направленную на регламентирование правового состояния объектов права и правосубъектности субъектов правоотношений, имеющую особую значимость, или требующую особого регулирования ввиду специфики предмета, или в связи с наступлением определенных ситуаций, а также влияющую на действия субъектов правоотношений посредством арсенала правовых средств обеспечения их законопослушного поведения путем гарантирования, обязывания, принуждения, стимулирования» [8]. Э.К. Утяшев предложил иную точку зрения. Данный автор рассматривает правовой режим как «специальное правовое регулирование специфических общественных отношений с помощью комплекса правовых средств, осуществляемое с целью достижения позитивного для общества и государства результата, в определенные, относительно кратковременные периоды времени, как правило, в не характерных для нормального (обычного) состояния ситуациях» [16, с. 258]. Наконец, А.А. Петров пишет: «виновата» высокая степень «химеризации» термина и понятия «правовой режим», т.е. лишение этого понятия собственного уникального содержания из-за «размывания» того смыслового поля, которое скрывается за словами «правовые режимы» [10].

Думается, акцентировать внимание на том, что режим в устоявшемся представлении есть главным образом некий «порядок», в современных условиях вряд ли правильно. И здесь, как представляется, нужно воспользоваться переводом французского слова «regime» [4, с. 912]. и рассматривать режим в управленческом смысле, как особый порядок управления. Достаточные основания для этого имеются. Дело в том, что, как справедливо полагает Б.А. Райзберг, управление есть сознательное воздействие человека, социальных групп, специально созданных органов на различные объекты и протекающие в окружающем мире процессы, на людей и отношения между людьми, осуществляемое с целью достижения определенного состояния объектов, придания процессам нужной направленности, получения желаемых, требуемых, намеченных результатов [12, c. 11].

Следует сказать, что сам по себе режим, как правовое явление, не может быть установлен, или возникнуть из правового обычая. Для этого требуется государственная воля управлять, в том числе осуществлять исполнительно-распорядительную деятельность в области обеспечения контроля исполнения законов и подзаконных нормативных актов. Цель режимного регулирования - это обеспечение национальной безопасности, охраны общественного порядка, создание благоприятных условий для деятельности как граждан - физических и юридических лиц так и государственными органами.

Краткое исследование, проделанное в настоящей статье, позволяет сформулировать авторское определение понятия «правовой режим». Таковым является специально урегулированное управление общественными публичными отношениями, направленное на ис- 
полнение нормативно-правовых актов как физическими, юридическими лицами так и должностными лицами, содержащих специальные обязательные требования организационной готовности к защите и обеспечению национальной безопасности и конституционных гарантий прав и свобод граждан.

\section{ЛИТЕРАТУРА}

1. Алексеев С.С. Общие дозволения и общие запреты в советском праве. М.: Юрид.лит.1989. С. 165

2. Бахрах Д.Н., Россинский Б.В., Старилов Ю.Н. Административное право: Учебник - М.: Норма. 2008. С. 478

3. Гессен В.М. 06 одной книге. // Право. Еженедельная юридическая газета.— Петроград, 1916. — № 51-52 (30 декабря). — Стб. С. $2015-2016$.

4. Ганьшина К.А, Французско — русский словарь: 51000 слов/К.А Ганшина - 7 издание, стереотип-М: Рус.яз 1977. С. 912.

5. Дюги Леон. Конституционное право. Общая тория государства. Дюги Леон, Тип. Т-ва И.Д. Сытина, г. Москва 1908, С. 706.

6. Евтихиев И.И. и Власов В.А. Советское административное право, Учебник для юридических институтов и факультетов. Всесоюзный институт юридических наук Министерства юстиции СССР. Юридическое издательство, М., 1946.

7. Козлов Ю.М., Попов Л.Л., Административное право: Учебник. - М.: Юристъ, 2000, С. 468.

8. Лясковский И.И. Правой режим как элемент правового регулирования/ Вестник Полоцкого гос. университета. Серия D. 2016. С. 145.

9. Мазутов Н.И и А.В. Мальков правовые режимы: Вопросы тории и практики: Правоведение 1996 № 1.

10. Оценка правовых режимов: подходы и методы: сборник научных трудов / отв. за вып. Н.А. Фролова, В.Ю. Панченко. — Красноярск: Сибирский федеральный университет. 2018. С. 15.

11. Российнский Б.В. Административное право: Учебник. - 6 -е изд. -М.: Норма: ИНФРА -М2019. С. 386.

12. Райзберг Б.А. Государственное управление экономическими и социальными процессами: учебное пособие / Б.А. Райзберг.- Москва: ИНФРА-М, 2021.-C. 11.

13. Спекторов А.С. Обсуждение учебника «Советское административное право» хроника научной жизни / А.С. Спекторов // Советское государство и прав0.- М., 1948. — № 3 (март). - С. 63.

14. Ситников А.П. Вопросы соотношения категорий «правовой режим», «правовое состояние», «правовой порядок». Вестник Челябинского государственного университета. Выпуск 21. № 31 (169).2009. С. 11.

15. Ю.А. Тихомиров. Курс административного права и процесса/ Ю.А Тихомиров. М.:1998- С. 400.

16. Утяшев Э.К. Правовые режимы: понятие, признаки, структура, методы правового регулирования//. Политика и право № 2.2014. С. 258.

17. Хохлова Е.М. Правой режим как общетеоретическая категория/ Пробелы в российском законодательстве № 6. 2017. С. 139. 